\title{
Dutch - Indonesian language mixing in Jakarta
}

\author{
Herman Giesbers
}

\section{Introduction}

Within the field of language contact and language change we see an increasing interest in the phenomenon of language mixing or language intertwining (Bakker 1992). See e.g. Bakker \& Mous (1994) for a recent overview of several mixed languages.

Bakker (1992:187) proposes a definition of a mixed language as ' $(.$.$) a$ language which shows positive genetic similarities, in significant numbers, with two different languages.' Such mixed languages can be related to two different language families. However, they differ from Pidgins and Creoles in that they combine the grammar of an existing language $A$ with the lexicon of a language B. Thus, the central process in language intertwining is not replacement, but combination.

Which language is language $\mathrm{A}$ or $\mathrm{B}$ is totally determined by social factors. Language A providing the grammatical system for the mixed language, is always the better known language, which is also the language of the closest outsiders. In general, this language $A$ is the language of the mothers in mixed families while language $B$ providing the lexicon, is the language of the fathers.

Bakker predicts from this model of intertwining that in a mixed language the grammar (syntax, morphology, phonology) is from language A, the lexicon from language B, and "free grammatical morphemes" or "function words" from both or from either of the languages.

Another way to look at the process of language mixing is suggested by Myers-Scotton (1992). She claims that her Matrix Language Frame (MLF) model of code-switching can also account for other manifestations of language contact including the formation of 'new' languages. An extensive overview of the MLF-model is Myers-Scotton (1993). Following Eliasson (1991) we can summarize the relevant features of this model as follows.

(i) There is a basic distinction between the matrix language (ML) and the embedded language (EL).

(ii) Three types of constituents can occur:

(a) ML+EL constituents, made up of elements from both ML and EL,

(b) ML islands, which draw grammatically and lexically on the ML only, 
(c) EL islands, which draw grammatically and lexically on the EL only.

(iii) The ML is determined by two extra-linguistic considerations:

(a) Speakers are more proficient in the ML than the EL.

(b) The ML is more widely employed in the speech community.

(iv) There are two important structural consequences of (iii):

(a) ML morphemes are more frequent than EL ones in $\mathrm{ML}+\mathrm{EL}$. constituents.

(b) ML islands are more common than EL islands.

(v) Two fundamental principles govern the structure of ML+EL constituents:

(a) The morpheme-order principle: the ML determines the morpheme order in $\mathrm{ML}+\mathrm{EL}$ constituents.

(b) The system-morpheme principle: the ML supplies all productive system morphemes (productive inflections and function words, a.o.) in $\mathrm{ML}+\mathrm{EL}$ constituents.

Replacing ML with 'language A' and EL with 'language B' shows immediately that both models are essentially not that different. However, as far as the formation of mixed languages is concerned we can see more rigid predictions from the MLF-model especially as a consequence of (iv) above and the 'system-morpheme principle' ( $v$ b).

Against this background we analyze an authentic conversation in Petjo, a mixed language of Indonesian and Dutch from Batavia/Jakarta. ${ }^{\prime}$ See section 2 for more details on this fragment.

In section 3 we present the results of our analysis, while section 4 gives an evaluation of our results regarding the above mentioned models of language intertwining. We end this paper with some concluding remarks.

\section{Source material}

Starting from the late 19th century there has been an interest in the mixture of Dutch and the mother tongue of the inhabitants of Indonesia, the former 'Dutch East Indies'. An extensive and critical overview of literature is De Vries (1992).

However, only a few of all these publications discuss the subject within the wider framework of processes of language contact or the genesis of 'new' languages (Sianturi 1976, De Gruiter 1990; 1994, Van Rheeden 1993; 1994a;b,

1 The name Petjo has been popularized by the author Tjalie Robinson, so we will follow his spelling conventions bere, although modern Indonesian spelling should require pecok or peco. 
Nur 1994). What is more, all the research specifically concerning Petjo has been based on secondary data, i.e. cabaret-like sketches in Petjo and particularly on Robinson (1991; first edition 1976), a collection of 47 short stories containing sketches of everyday life situations of Indo boys living in former Batavia, the present Jakarta. Obviously, such secondary data run the risk of bias in that the material has been influenced by its creators, e.g. because of idiosyncrasies or simply because of an endeavour at being humorous. Moreover, all the stories in Robinson (1991) show the same structure: a dialogue between a first person narrator and his friend Bentiet preceded by a short introduction of the situation.

The data in this paper is a recording of a conversation between two old men (both 83 years old) who have been friends for many years. Niel visits Sadikin on the occasion of halal bihalal, the customary practice to come together after the Islamic fasting month Ramadan. The conversation has been audio taped with a hidden microphone by a student of the Dutch Department of the Universitas Indonesia, in April 1992. The total time of the fragments which could be used for further analysis comprises about five and a half minutes.

This conversation has been transcribed by the above mentioned student, a native speaker of Indonesian, and particularly of Melayu Betawi 'Jakarta Malay', the Jakarta variety of standard Indonesian. He also discussed his transcription with one of the informants, and, finally, we ourselves checked the transcription once again. ${ }^{2}$

Both informants are proficient in Dutch and in Indonesian. Their fathers were Dutch soldiers and both visited the Europese Lagere School during colonial times. ${ }^{3}$ Sadikin spoke Dutch to his father and his own wife, and Indonesian to his Jayanese mother and his children. Niel's father died when he was 13 years old. His Indonesian -Chinese mother married again with a Indonesian-Chinese man, so Niel used to speak less Dutch than Sadikin. With his wife and children he talks the Jakarta variety of Indonesian. Both men say to use Petjo particularly when visiting friends, walking around, etc. ${ }^{4}$

2 Many thanks are due to Atajuddin Nur who in a very creative manner recorded a unique fragment of living Petjo, transcribed it conscientiously and had no objection to put this material at my disposal. Here, I also want to thank Juwita Samosir for her first comments on the transcription and its particularities from Jakarta Malay.

${ }^{3}$ Groeneboer (1993) contains an exhaustive description of Dutch educational policy in Indonesia until 1950 ,

4 Several Indonesians with a near-native command of Dutch told us the same practice: Petjo is only used in the inner circle of friends. In passing, this confirms the observation in Robinson (1991:6) that Petjo was/is not only a language for the Indos, the people of mixed descent, but also for 'fullblood' Indonesians with a proficiency in Dutch. Such a situation is not always common with respect to the use of a mixed language; cf. Bakker (1992). 


\section{Results}

On the basis of section 1 it is to be expected that in Petjo the matrix language (Myers-Scotton 1993) or language A (Bakker 1992) is Indonesian particularly its Jakarta variety, Jakarta Malay. ${ }^{5}$ For this is the language of the speech community of our informants and the language of their "closest outsiders". Moreover, we can expect that this language is undoubtedly their most proficient language considering the fact that the use of Dutch is not relevant anymore since a long time. Van Rheeden $(1993: 146 ; 159)$ corroborates this expectation in stating that the syntax of Petjo in Robinson (1991) is essentially Indonesian.

Indonesian being the matrix language/language $\mathrm{A}$ we expect a predominantly Indonesian grammar, predominantly Dutch lexical morphemes, and free grammatical morphemes from both or from either of these languages. It can be noted here that Van Rheeden (1993:145) found a mixture of "function words" with conjunctions, articles, personal pronouns and prepositions predominantly being Dutch, demonstrative and possessive pronouns equally being Dutch and Indonesian, and relative pronouns and question words predominantly being Indonesian. ${ }^{6}$

In particular following the MLF-model, we should expect more linguistic elements from Indonesian (more ML islands), and $M L+E L$ islands with a completely Indonesian word order and Indonesian "system morphemes" only.

Regarding the formulated predictions with respect to the proportion of elements from the matrix language (ML) and the embedded language (EL) respectively we firstly present some relevant figures. It should be kept in mind here that cognates like $y a / j a$ 'yes', kobov 'cowboy' or pintar/pienter 'clever, smart' are excluded from these figures except for the total number of words.

In our fragment, we were able to count 426 words. This number includes 12 bound morphemes in the case of mixed words, i.e. a word with a lexical morpheme from one language and at least one bound morpheme from the other one. An example is di-bestel "has been ordered' with the Indonesian passive forming prefix $d i$ - bound to the verb stem bestel from Dutch. In all other -'monolingual'- cases we did not count bound morphemes separately.

5 For convenience sake, we will use Indonesian is a cover term for buth standard Indonesian and Jakarta Malay, unless otherwise needed.

6 Van Rheeden includes yang (mwane in Jakarta Malay) in the category of relative pronouns. Actually, yong is not a real relative pronoun, but a 'ligature particle' which can be used in several ways to single one item out of a class. The term 'ligature particle' has been suggested by Anton M. Moeljono from the Universitas Indonesia (personal communication). 
The all-over proportion of unequivocally Indonesian (ML) words is $22.8 \%$ $(\mathrm{n}=97)$ including 12 morphemes bound to Dutch lexical morphemes. Dutch bound morphemes with an Indonesian lexical morpheme did not come up.

A division of the total number of words into function words and lexical morphemes results in a proportion of $13.8 \%(27 / 196)$ function words and 25.6 $\%(55 / 215)$ lexical morphemes from Indonesian. ${ }^{\top}$ Adding the 12 bound morphemes to the Indonesian function words increases the $\mathrm{ML}$ proportion of 'grammatical morphemes' only slightly to $18.75 \%$ (39/208).

These bare figures show a low proportion of linguistic elements from Indonesian as the ML in this Petjo conversation. This impression is only reinforced when we take a closer look at what words come from Indonesian.

Starting with the lexical morphemes we can observe that $\mathrm{ML}$ nouns have a proportion of $35.5 \%(\mathrm{n}=27)$ in the total number of nouns $(\mathrm{N}=76)$. At first glance, this seems somewhat high compared to the ML lexical morphemes proportion of $25.6 \%$, but almost all these nouns (18) are related to the halal bihalal visit. Thus, they can be interpreted as 'cultural loans' and as such almost inevitable in use, particularly for Niel and Sadikin who lived all their lifetime in Indonesia. Some examples of these nouns are Lebaran, the Indonesian word for Idul Fitri (an Arabic loan) the feast celebrating the end of the fasting month Ramadan, names for several kinds of cake like nastar, kue keju, etc. Moreover, three other Indonesian nouns were specific 'Indonesianized' proper names.

Thirteen adjectives out of a total number of 43 are Indonesian, i.e. $30.2 \%$. However, this category of lexical morphemes is much more varied (10 types) and less related to specific Indonesian cultural phenomena. Examples are bener (Jakarta variant) 'correct, right', kambuh 'suffer a relapse', pantas-an 'of course', ke-kenyang-an 'too full, overly full'.

Only 7 verbs are Indonesian, that is $13 \%$ of a total number of 54. Four times this was the verb sempat 'have opportunity to, still be able to'. An example of a verbal form with derivational affixation (i.c. -an) is $i k u t-i k u t-a n$ 'follow along'. We did not find Indonesian verbs with Dutch inflectional morphemes, or with Dutch affixes.

A closer examination of the function words reveals the same tendency: not only the total number of linguistic elements from the ML is small, but above that we find only some specific function words represented.

? Thrce times we could not categorize a word. In determining the word class of Indonesian words we based ourselves on the works of indonesian linguists (Kridalaksana 1990, e.g.) and on reference wotks tike Wolff et al. (1987), Moeliono (ed.) (1988), Moeliono et al. (1990). In a few cases we had to consult a native speaker of Indonesian. 
No less than $63 \%(\mathrm{n}=17)$ of the 27 function words from Indonesian are 'pragmatic' or 'phatic particles' (Kridalaksana 1990:111-117), elements, often specific to colloquial speech, that are used to start, to structure or to 'colour' the speaker's utterances. Some frequent examples are $\operatorname{nih}(\mathrm{n}=5)$, a particle pointing to something nearby, and $\sin (n=4)$, a multi-functional particle that can be used to soften a question, to mark a topic or to emphasize a reason given.

Furthermore, all pronouns, question words and copulas are in Dutch, the EL. From the 17 conjunctions there is only one from the $\mathrm{ML}$, ampe (Jakarta variant) 'so that', only one out of 16 prepositions is Indonesian, the Jakarta variant ame 'with', and, finally, all the three Indonesian articles out of a total of 9 are represented by the rather specific form $s i$, only used before the names of those with whom the speaker and the interlocutor are intimate. The five remaining Indonesian function words are the ligature particle yang $(\mathrm{n}=4)$ ( $\mathrm{cf}$. note 6) and nanti 'next, later'.

Regarding adverbs we meet with 6 Indonesian adverbs, i.e. $7.9 \%$ out of a total of 76 .

Above, we already discussed 12 bound morphemes from the ML linked to EL lexical morphemes. However, in this case as well we find very little variation in that only three types come up. Six times we meet with a mixed word including the prefix $d i$ - (cf. di-bestel above), five times including the suffix -nya, and one example with the affix combination $k e$ - an. Actually, -nya is a derivative of the personal pronoun dia 'he, she', but it serves several functions like genitive marking, noun formation, or as a definite article. Consider (1) as an example with -nya functioning as a definite article. ${ }^{8}$

$$
\begin{aligned}
& \text { Water-nya op Niel? } \\
& \text { Water-the up Niel? } \\
& \text { 'Is there any water left Niel?' }
\end{aligned}
$$

The affix combination $k e$ - an has been used in (2) with the Dutch adjective lekker 'tasty, delicious' as the lexical morpheme. In this example, $k e$ - an forms a new adjective more or less meaning 'too delicious'.

(2) Nee nee, genoeg, nanti bisa ke-lekker-an (-)

No no enough next can affix-delicious-affix

"No no, enough, it might happen that it is getting too delicious for me $(-)^{\prime}$

\footnotetext{
Phonological peculiarities have been omitted in the examples if they are momentarily irrelevant.
} 
From a formal point of view we have to conclude that Indonesian, although being the ML, is hardly present in this Petjo conversation, and this holds for lexical morphemes as well as for function words.

On the other hand, we have to point to other linguistic characteristics which unmistakably show the Indonesian character of this Petjo.

First of all, its syntax appeats to be Indonesian in a very consistent way.

All sentences show SVO word order including in those cases where Dutch grammar should require a VS or SOV word order. Consider (3) where Dutch word order should be Gisteren (-) kwam mijn dochter (-). An incorrect SVO word order in a subordinate clause can be found in (9) below.

$$
\begin{aligned}
& \text { Gisteren, (-), mijn dochter, met haar familie, komen hier } \\
& \text { Yesterday my daughter with her family come here } \\
& \text { 'Yesterday, my daughter and her family came here' }
\end{aligned}
$$

Another striking phenomenon is the omitting of finite verbs or copula which, again, is conflicting with Dutch grammar, but which is not impossible in Indonesian. We met with a total of 33 such observations. See (4) and (5), and (11) below. In (4) the copula ben 'am' is missing, in (5) we should expect a verb like (weg)gaan 'to leave'.

$$
\begin{aligned}
& \text { Niet. Ik al oud voor zoiets. } \\
& \text { No I already old for so-something. } \\
& \text { 'No, I'm too old for something like that.' }
\end{aligned}
$$

$$
\begin{aligned}
& \text { Lah, waarom zo vlug jij? } \\
& \text { Phatic particle why so fast you? } \\
& \text { 'Oh, why do you want to leave so quickly?' }
\end{aligned}
$$

Further, we found 17 sentences with 'topic drop', the omitting of a subject or object when it is already clear from the context which topic is discussed. This phenomenon too is very common and not at all ungrammatical in Indonesian unlike Dutch where it leads to ungrammatical/unacceptable sentences for the most part. See e.g. (6) where in Dutch the subject $i k$ ' $I$ ' should have been realized (and a copula too, of course). In (6), Sadikin answers the question if he has already visited a doctor.

$$
\begin{array}{ll}
\text { Al, maar de hele dag lemas. } \\
\text { Already but the whole day languid. }
\end{array}
$$

'Yes, but I've been feeling weak the whole day.' 
Additionally, we observed the Dutch negation particle niet 'not' always in pre-verbal position which is not always in accordance with Dutch syntax, but, once again, seems to be influenced by Indonesian. An example is $I k$ niet durf for Ik durf niet 'I don't dare'.

Finally, the last observation that gives further support to the impression of an all Indonesian syntax is the missing of (Dutch) articles $(n=4)$ as in (7). ${ }^{9}$

$$
\begin{aligned}
& \text { Ik ga naar WC. } \\
& \text { I go to toilet. } \\
& \text { 'I'm going to the toilet.' }
\end{aligned}
$$

In addition, it should be noted, however, that the word order within NP's is consistently Dutch, i.e. modifier-head unlike Indonesian head-modifier. Moreover, we can observe some utterances with a 'mixed' word order, i.e. a word order which is not clearly Dutch nor Indonesian. See e.g. (8), in which the SV word order $i k$ vasten is Indonesian (cf. (3) above), but the position of alleen seems to be Dutch. Compare the Indonesian lima hari saja 'five day only' to Dutch (-) maar/slechts vijf dagen 'only five days'.

$$
\begin{aligned}
& \text { Deze vastenmaand, ik vasten alleen vijf dagen. } \\
& \text { This fastingmonth I fast only five days. } \\
& \text { 'This fasting month I fasted only for five days.' }
\end{aligned}
$$

Observations on the phonological, morphological, semantic and lexical level too support the idea of a predominantly Indonesian grammar in Petjo.

On the phonological level we find as most striking phenomenon the reduction of consonant clusters, as in soiet < zoiets 'something like that', maan < maand 'month', or eers < eerst 'first'. Cf. Kridalaksana (1989), Moeliono (1989), a.o., with regard to consonant clusters in Indonesian.

On the morphological level, we can observe the doubling of Dutch lexical elements $(n=2)$ as in lopen lopen 'walk walk' = 'walking around'. As far as the verb system is concerned we found a total of 14 incorrect present tense singular forms, all of these concerning the second/third person. Seven times there has been used an infinitive form, and seven times the suffix $-t$ has been omitted. ${ }^{10}$ Cf. (3) above with the infinitive form komen for kom-t, and (9) with maak instead of the correct form maak- $t$.

9 Indonesian does not have articles comparable to Dutch de/het/een 'the/a(n)'. Cf. the information above concerning yang, - -nya, si.

10 Particularly with respect to Indonesian Dutch, it is not always clear whether this $-t$ omission is a morphological process or a manifestation of word final ( $t$ ) deletion. Cf. for further discussion Giesbers (to appear). 
(9) (-) als mijn vrouw maak koekjes (-)

if my wife make cookies

' $(-)$ if my wife made cookies $(-)$ '

Such incorrect forms could be due to influence from Indonesian which does not have an inflectional morphology.

The same holds true for the expression of temporal relations, a phenomenon on the semantic level. Indonesian does not have a tense system, but expresses time references (and aspect and modality as well) by lexical and contextual means. In our Petjo conversation, only present tense forms have been used. Following Dutch grammar, in five utterances a past tense form should have been used (see (10)), while seven utterances should require a perfective form. Utterance (3) above, e.g., should require the perfective is ... geweest/gekomen, because of the element gisteren and the further context of the utterance.

$$
\begin{aligned}
& \text { In de tijd, ik blijf in Semarang (-) } \\
& \text { In the time I stay in Semarang } \\
& \text { "At that time I was in Semarang (-)" }
\end{aligned}
$$

On the lexical level, finally, there is the remarkable finding of the many literal, word for word translations of Indonesian idiomatic expressions and constructions. One striking example is (11), the question preceding (6) above. This utterance is a literal translation of Sudah ke dokter?

$$
\begin{aligned}
& \text { Al naar dokter? } \\
& \text { Already to doctor? } \\
& \text { "Have you already been to the doctor?" }
\end{aligned}
$$

Some other examples are niet wat 'not what' from nggak apa apa (literally 'not what what') 'does not mind', hoe hij? 'how he?' from gimana dia? 'how is he?', een maand gisteren 'a month yesterday' from bulan kemarin 'last month', is ter wat? 'is there what?' from ada apa? 'what is the matter?', etc. etc. Even a shibboleth-like expression as sudah which is also known and used by Indos in the Netherlands, has been translated into laat maar 'it's allright'. 25 times we found such an 'Indonesianism'.

In view of the above we can come to the conclusion that our sample of Petjo is almost exclusively Dutch (the EL/language B) as far as its lexical elements are concerned. This holds for lexical morphemes as well as for grammatical morphemes, and maybe this is a rather surprising finding considering the fact that this Petjo has been used by Jakarta informants who have never been outside Indonesia. 
On the other hand, the grammar of this Petjo seems to be predominantly Indonesian in quite a consistent way. Note, however, that some grammatical features of Dutch are preserved like the above mentioned modifier-head word order within NP's. Some other Dutch grammatical features as inflections for plural forms and present tense singular, a.o., are most probably due to the extensive use of Dutch lexical elements.

\section{Discussion and concluding remarks}

A comparison of our data from real Petjo, spoken in Jakarta in 1992, with data based on the 'literary' Petjo from the writer Tjalie Robinson as analyzed by Van Rheeden (1993), shows the following differences.

Firstly, a rather striking difference appears to be that the Jakarta Petjo is more consistent in a somewhat unexpected way, i.e. its lexical material is overwhelmingly Dutch including function words like demonstratives, possessives and question words which are in Robinson's Perjo equally Dutch and Indonesian, or predominantly Indonesian. Admittedly, this state of affairs can partly be related to the many literal translations of Indonesian idiom and constructions.

On the other hand, the grammar of Jakarta Petjo seems to be Indonesian in a more consistent way than the grammar of Robinson's Petjo. Sentence word order is consistently Indonesian including the position of niet 'not' which in Robinson's Petjo is sometimes Dutch (Van Rheeden 1993:126). Time reference seems hardly to be expressed by tense, but has to be inferred from the context and from lexical means. A striking example in this respect is (11) in section 3 in which al 'already' (from Indonesian sudah) expresses the perfective meaning of this utterance. Bound morphemes with a lexical morpheme from another language only come from Indonesian, whereas Van Rheeden (1993:130) gives some examples of the opposite, e.g., ge-tiemploeng 'plunged into water' with the Dutch past participle prefix ge-.

Jakarta Petjo shows less variation with regard to present tense singular forms because it does not show the form $i k V_{-l}$, i.e. a first person singular form with the second/third person singular suffix $-t$. A frequent example from Robinson's text is $i k$ seg-t 'I say'.

Finally, we have the impression that the pronunciation as it is suggested by Robinson's spelling conventions is far more variable than it is in our sample. However, we have to admit here that we ourselves did not analyze the phonological aspects of our sample in full detail. Moreover, an arbitrary spelling system used by a non-linguist like Robinson is not very reliable, of course.

In view of the above we can categorize Petjo, particularly its real life variant, as a clear case of language mixing/intertwining (cf. section 1), the combination of the grammar from language A, here Indonesian, with the lexicon from language 
B, here Dutch. ${ }^{11}$ In addition, we can say that Petjo is an example of a mixed linguage that tends to take its free grammatical morphemes from one of the two languages, here language $B$. Maybe, this has been made possible by the fact that in many respects Indonesian is an isolating language. Note, however, that Indonesian derivational affixes as, e.g., $k e-a n$ in (2) have not been replaced by Dutch grammatical elements. Thus, language typology or at least specific characteristics of the relevant languages seems to play its role in the process of language mixing.

With regard to the MLF-model we have to conclude that this model in general is too robust in accounting for language mixing. $\mathrm{ML}$ islands, i.e. constituents in Indonesian only, are not more common than EL islands, constituents completely in Dutch. On the contrary, if we should interpret all the stretches of discourse including Dutch lexical material as EL islands, we would find an inconsistency with the prediction that EL islands draw grammatically and lexically on the EL only. For, in these 'EL islands' the syntax and other grammatical features as well appear to be predominantly Indonesian.

On the other hand, however, Myers-Scotton's MLF-model seems to be right concerning its predictions about $M L+E L$ constituents. Cf (2) for such a $M L+E L$ constituent in which only the lexical morpheme lekker is from the EL, but the grammatical structure and its system morphemes are unequivocally from the ML. Only two cases probably deviate from this ML+EL constraint, one of these being (12)

$(-)$ as water-nya op, kraan-nya di-draai-t if water-the up tap-the pass. prefix turn-verb suffix

' $(-)$ if there isn't any water left, turn on the tap'

In the ML+EL constituent kraan-nva di-draai-t the Dutch (EL) verbal suffix $-t$ comes up together with the Indonesian (ML) system morphemes -nya and di-.

For the time being we want to conclude that the notion of language intertwining accounts for the phenomenon of language mixing in a better way than the MLF-model, although the MLF-model gives a fairly good insight in what is going on in ML+EL constituents.

Finally, we want to conclude this paper with the following comment. Although the analyzed sample of Jakarta Petjo is not that large, it has shown some important information in addition to the analysis of Robinson's 'literary'

11 In passing, it is interesting to know that one of the informants considered his language use as Dutch, but with many deviations. 
Petjo. In 1995, it is the 50th anniversary of the declaration of independence of the Republic of Indonesia. Maybe, this could be a good reason to start further research of Petjo as it is still spoken in Jakarta.

\section{References}

Bakker, P. (1992) 'A language of our Own': the Genesis of Michif, the Mixed Cree-French Language of the Canadian Metis, PhD dissertation, UvA Amsterdam.

Bakker, P. and M. Mous, eds. (1994) Mixed Languages. 15 Case Studies in Language Intertwining, IFOTT, Amsterdam.

De Gruiter, M. (1990) Het Javindo, de verboden taal, Moesson, Den Haag.

De Gruiter, M. (1994) 'Javindo, a contact language in pre-war Semarang', in P. Bakker and M. Mous, eds., Mixed Languages. 15 Case Studies in Language Intertwining, IFOTT, Amsterdam, 151-159.

De Vries, J.W. (1992) 'Indisch-Nederlands: verleden, heden en toekomst', in W. Willems, red., Sporen van een Indisch verleden. 1600-1942, COMT, Leiden, 125-139.

Eliasson, S. (1991) 'Models and Constraints in Code-switching Theory' in Papers for the Workshop on Constrainis, Conditions and Madels, ESF, Strasbourg, 17-50.

Giesbers, H. (to appear) 'Dutch in Indonesia. Language Attrition or Language Contact?', in S. Kroon and J. Klatter-Folmer, eds., Dutch Overseas: Studies in Language maintenance, shift and loss in Dutch emigrants, John Benjamins, Amsterdam/Philadelphia.

Groeneboer, K. (1993) Weg tot het westen. Het Nederlands voor Indié 1600-1950, KITLV Uitgeverij, Leiden.

Kridalaksana, H. (1989) 'The Impact of Borrowing on the Structure of Language. -The Indonesian Case-', in K. Groenebuer, ed., Studi Belanda di Indonesia/Nederlandse Studiën in Indonesië. Djambatan, Jakarta, 291-297.

Kridalaksana, H. (1990) Kelas Kata dalam Bahosa Indonesia, Gramedia, Jakarta.

Moeliono, A.M. et al, eds. (1988) Tata Bahasa Baku Bahasa Indonesia, Balai Pustaka, Jakarta.

Moeliono, A. M. (1989) 'Intellectualization of the Lexicon: The Development of Indonesian Terminologies', in K. Groeneboer, ed., Srudi Belanda di Indonesia/Nederlandse Studièn in Indonesië, Djambatan, Jakarta, 225-228.

Moeliono, A. M. et al, eds. (1990³) Kamus Besar Bahasa Indonesia, Balai Pustaka, Jakarta.

Myers-Scotton, C. (1992) Possible structural strategies in Pidgin/Creole formation, Paper given at Annual Meeting of Society for Pidgin and Creole Linguistics, Los Angeles.

Myers-Scotton, C. (1993) Duelling Languages. Grammatical Stnucture in Codeswitching, Clarendon Press, Oxford.

Nur, A. (1994) Beberapa karakteristik bahasa Belanda Pecuk dan hubunganrya dengan karakteristik umum bahasa Pijin dan Kreol, M.A. Thesis, Fakultas Sastra Universitas Indonesia Jakarta.

Robinsun, T. (1991 $)$ Ik en Bentiet, Moesson, Den Haag.

Sianturi, S.R. [1976] Apakah Peco termasuk bahasa pidgin atau kreol dan pengaruh bahasa manakah yang paling dominan terhadaphya, M.A. Thesis, Fakultas Sastra Universitas Indonesia Jakarta.

Van Rheeden, H. (1993) Het Petjo van Batavia. Ontstaan en structuur van de taal van de Indo's, M.A. Thesis, UvA Amsterdam.

Van Rheeden, H. (1994a) 'Petjo: the mixed language of the Indos in Batavia', in P. Bakker and M. Mous, eds., Mtxed Langwages. 15 Case Studies in Language Intertwining, IFOTT, Amsterdam, 223-237,

Van Rheeden, H.A. (1994b) 'Het Petjo van Batavia. Een gemengde taal', Gromma/TTT 3, 2, 89-101.

Wolff, J. U., D. Oetomo and D. Fietkiewicz (1987) Beginning Indonesian through Self-instruction ( 3 volumes), Gramedia, Jakarta. 